\title{
Indole Alkaloids from Marine Sources as Potential Leads against Infectious Diseases
}

\author{
Paulo H. B. França, ${ }^{1}$ Daniel P. Barbosa, ${ }^{2}$ Daniel L. da Silva, ${ }^{1}$ \\ Êurica A. N. Ribeiro, ${ }^{2}$ Antônio E. G. Santana, ${ }^{1}$ Bárbara V. O. Santos, ${ }^{3}$ \\ José M. Barbosa-Filho, ${ }^{3}$ Jullyana S. S. Quintans, ${ }^{4}$ Rosana S. S. Barreto, ${ }^{4}$ \\ Lucindo J. Quintans-Júnior, ${ }^{4}$ and João X. de Araújo-Júnior ${ }^{1,2}$ \\ ${ }^{1}$ Institute of Chemistry and Biotechnology, Federal University of Alagoas, University City, BR 101, KM 14 Norte, \\ Tabuleiro dos Martins, 57072-970 Maceio, AL, Brazil \\ ${ }^{2}$ School of Nursing and Pharmacy, Federal University of Alagoas, Av. Lourival de Mello Motta, S/N, Tabuleiro dos Martins, \\ 57072-970 Maceió, AL, Brazil \\ ${ }^{3}$ Laboratory of Pharmaceutical Technology, Federal University of Paraiba, 58051-900 João Pessoa, PB, Brazil \\ ${ }^{4}$ Department of Physiology, Federal University of Sergipe, 49000-100 São Cristóvão, SE, Brazil
}

Correspondence should be addressed to João X. de Araújo-Júnior; jotaaraujo2004@gmail.com

Received 23 February 2014; Revised 25 April 2014; Accepted 25 April 2014; Published 5 June 2014

Academic Editor: Xudong Huang

Copyright (C) 2014 Paulo H. B. França et al. This is an open access article distributed under the Creative Commons Attribution License, which permits unrestricted use, distribution, and reproduction in any medium, provided the original work is properly cited.

Indole alkaloids comprise a large and complex class of natural products found in a variety of marine sources. Infectious diseases remain a major threat to public health, and in the absence of long-term protective vaccines, the control of these infectious diseases is based on a small number of chemotherapeutic agents. Furthermore, the emerging resistance against these drugs makes it urgently necessary to discover and develop new, safe and, effective anti-infective agents. In this regard, the aim of this review is to highlight indole alkaloids from marine sources which have been shown to demonstrate activity against infectious diseases.

\section{Introduction}

Seas and oceans occupy more than $75 \%$ of the Earth's surface and contain nearly all groups of organisms, including representatives of 34 out of 36 phyla described. Thus, marine ecosystems can be considered as having the greatest phyletic biodiversity with virtually unlimited biotechnological potential [1]. The marine environment is massively complex, consisting of extreme variations in pressure, salinity, temperature, and biological habitats that have led to the production of several novel structures with unique biological properties, which may not be found in terrestrial natural products [2]. In the past 30-40 years, marine plants and animals have been the focus of a worldwide effort to define the natural products of the marine environment. A small number of marine plants, animals, and microorganisms have already yielded more than 12,000 novel chemicals, with hundreds of new compounds still being discovered every year. These discovery efforts have yielded several bioactive metabolites that have been successfully developed by the pharmaceutical industry [3]. A variety of marine sources including sponges, tunicates, red algae, acorn worms, and symbiotic bacteria have been shown to generate indole alkaloids, which represent the largest number and most complicated of the marine alkaloids [47]. The alkaloids obtained from marine organisms frequently possess novel frameworks which cannot be found in terrestrially related organisms. Marine metabolites often possess complexities such as halogen substituents [8]. In addition, bearing in mind that several species of organisms are associated with cyanobacteria and bacteria, it is considered that several natural products originating in microorganisms can be isolated from marine animals [9]. Indole alkaloids have been shown to exhibit a wide array of biological activities such as opioid receptor agonistic [10], antibacterial [11,12], antifungal [13, 14], anti-inflammatory [15], antileishmanial [16, 17], antiplasmodial [18, 19], anti-HIV [20], cytotoxic [21], glucose 
uptake stimulatory [22], larvicidal [23], trypanocidal [24], and vasodilator $[25,26]$ and inhibition of cholinesterase [27], indoleamine-2, 3-dioxygenase [28], calmodulin [29], and CB1 cannabinoid receptor [30]. Infectious diseases caused by bacteria, fungi, viruses, and parasites are still a major threat to public health, despite the tremendous progress in human medicine. The high prevalence of these diseases and the emergence of widespread drug resistance developed by these parasites to current treatments, leading to reduction of their efficacy and consequent increase in the cost of conventional treatments, highlight the need for novel and effective therapeutic alternatives with fewer or no side-effects. Their impact is particularly large in developing countries due to the relative unavailability of medicines $[31,32]$.

Therefore, in continuation of our research on bioactive molecules from natural origin [33-53] and plant extracts [5463 ] we offer this compilation of the indole alkaloids from marine sources.

In this review, literature was covered in order to highlight alkaloidal compounds with an indole moiety which have been shown to demonstrate activity against infectious diseases.

\section{Indole Alkaloids from Marine Sources}

Manadomanzamines A and B (Figure 1), $\beta$-carbolines with a novel rearrangement of the manzamine framework, were isolated from an Indonesian sponge Acanthostrongylophora sp. These compounds showed significant activities against Mycobacterium tuberculosis, with MIC values of 1.9 and $1.5 \mu \mathrm{g} / \mathrm{mL}$, respectively. Manadomanzamines A and B were also active against human immunodeficiency virus (HIV1) with $\mathrm{EC}_{50}$ values of 7.0 and $16.5 \mu \mathrm{g} / \mathrm{mL}$. Furthermore, manadomanzamine A was active against the fungus Candida albicans with an $\mathrm{IC}_{50}$ of $20 \mu \mathrm{g} / \mathrm{mL}$, whilst manadomanzamine $\mathrm{B}$ exhibited activity against the fungus Cryptococcus neoformans with $\mathrm{IC}_{50}$ value of $3.5 \mu \mathrm{g} / \mathrm{mL}$ [64].

Manzamine $\mathrm{A}$, a $\beta$-carboline alkaloid present in several marine sponge species, has been shown to inhibit the growth of the rodent malaria parasite Plasmodium berghei in vivo. More than $90 \%$ of the asexual erythrocytic stages of $P$. berghei were inhibited after a single intraperitoneal injection of manzamine A into infected mice. Moreover, it was demonstrated that immunostimulatory effects caused by the compound play an important role in preventing mouse death due to fulminating recurrent parasitemia in animals treated with $100 \mathrm{mmol}$ per $\mathrm{kg}$ of manzamine A [65].

Several manzamine-type alkaloids were also isolated from an Indonesian sponge of the genus Acanthostrongylophora. The $\beta$-carbolines (+)-8-hydroxymanzamine $\mathrm{A}$ and 6-hydroxymanzamine E (Figure 1) showed strong activity against $M$. tuberculosis $\mathrm{H} 37 \mathrm{Rv}$ with $\mathrm{MIC}$ values of 0.9 and $0.4 \mu \mathrm{g} / \mathrm{mL}$, respectively. Manzamine A and (+)-8hydroxymanzamine were strongly active when tested against Plasmodium falciparum chloroquine-sensitive D6 clone and chloroquine-resistant W2 clone, showing, respectively, $\mathrm{IC}_{50}$ values of 4.5 and $6.0 \mathrm{ng} / \mathrm{mL}$ toward the former and equally $8.0 \mathrm{ng} / \mathrm{mL}$ toward the latter. Moreover, manzamine A, manzamine $\mathrm{Y}$, and 6-hydroxymanzamine E (Figure 1) have shown significant activity against Leishmania donovani, with $\mathrm{IC}_{50}$ values of $0.9,1.6$, and $2.5 \mu \mathrm{g} / \mathrm{mL}$, respectively [66].

Investigation of bioactivity of manzamine alkaloids isolated from an Okinawan sponge Amphimedon sp. revealed active compounds against Trypanosoma brucei brucei and $P$. falciparum. Zamamidine C (Figure 1), 3,4-dihydromanzamine J $N$-oxide, and manzamine A showed inhibitory activities in vitro against T. b. bruce $i$ with $\mathrm{IC}_{50}$ values of $0.27,4.44$, and $0.04 \mu \mathrm{g} / \mathrm{mL}$, respectively, and $P$. falciparum with $\mathrm{IC}_{50}$ values $0.58,7.02$, and $0.97 \mu \mathrm{g} / \mathrm{mL}$, respectively [67].

Seven $\beta$-carboline-based metabolites, designated as eudistomins $\mathrm{Y}_{1}-\mathrm{Y}_{7}$ (Figure 2), were isolated from a tunicate of the genus Eudistoma collected in South Korea. These new metabolites differ from previously isolated marine metabolites due to the presence of a benzoyl group attached to the $\beta$-carboline nucleus at C-1. Eudistomin $\mathrm{Y}_{6}$ exhibited moderate antibacterial activity against Gram-positive bacteria Staphylococcus epidermidis ATCC12228 and B. subtilis ATCC 6633 with MIC values of 12.5 and $25 \mu \mathrm{g} / \mathrm{mL}$, respectively, but showed no inhibitory activity toward the other two strains of Gram-positive bacteria, S. aureus ATCC 6538 and M. lutes ATCC 9341, and the Gram-negative bacteria including E. coli ATCC 11775, Salmonella typhimurium ATCC 14028, and Klebsiella pneumoniae ATCC 4352. Eudistomins $\mathrm{Y}_{1}$ and $\mathrm{Y}_{4}$ also displayed the same selectivity as eudistomin $\mathrm{Y}_{6}$ but demonstrated weak antibacterial activity against the two strains of bacteria S. epidermidis ATCC12228 and B. subtilis ATCC 6633 with MICs of 50 and $200 \mu \mathrm{g} / \mathrm{mL}$, respectively [68].

Investigation of the $\mathrm{CH}_{2} \mathrm{Cl}_{2}$ extract from the bryozoan Pterocella vesiculosa, collected in New Zealand, has led to the isolation of 5-bromo-8-methoxy-1-methyl- $\beta$-carboline (Figure 2). This alkaloid was evaluated for antibacterial and antifungal activities and showed inhibitory action toward the Gram-positive bacterium B. subtilis and the fungi C. albicans and Trichophyton mentagrophytes with MID ranges of 2-4, 45 and $4-5 \mu \mathrm{g} / \mathrm{mL}$, respectively [69].

An indole spermidine alkaloid, didemnidine B (Figure 3), was described in the New Zealand ascidian Didemnum sp. Evaluation of the compound against Trypanosoma brucei rhodesiense, Trypanosoma cruzi, L. donovani, and Plasmodium falciparum K1 chloroquine-resistant strain indicated didemnidine $\mathrm{B}$ to be mildly active toward the malaria parasite with $\mathrm{IC}_{50}$ value of $15 \mu \mathrm{M}$ [70].

In addition, chemical investigations of the tropical marine sponge Hyrtios sp. have resulted in the isolation of several alkaloids, which were evaluated as C. albicans isocitrate lyase inhibitors. Out of the compounds tested, the bisindole alkaloid hyrtiosin B (Figure 4) showed the most potent inhibitory activity with an $\mathrm{IC}_{50}$ value of $50.7 \mu \mathrm{M}$. Other compounds comprised simple indole alkaloids, namely, 1carboxy-6-hydroxy-3,4-dihydro- $\beta$-carboline, 5 -hydroxy- $1 H$ indole-3-carboxylic acid methyl ester, serotonin, hyrtiosin A, and 5-hydroxyindole-3-carbaldehyde (Figure 3) revealed only moderate to weak activity against $C$. albicans isocitrate lyase, with MIC values ranging between 39.8 and $152.9 \mu \mathrm{M}$. By comparing their chemical structures, it was found that the enzyme inhibitory activities of these 5-hydroxyindoletype alkaloids are markedly affected by a substitution of 


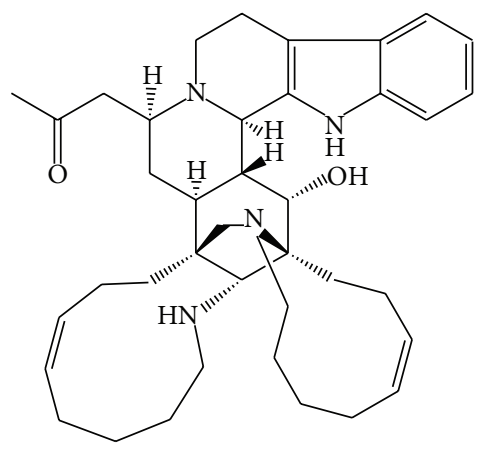

Manadomanzamine A

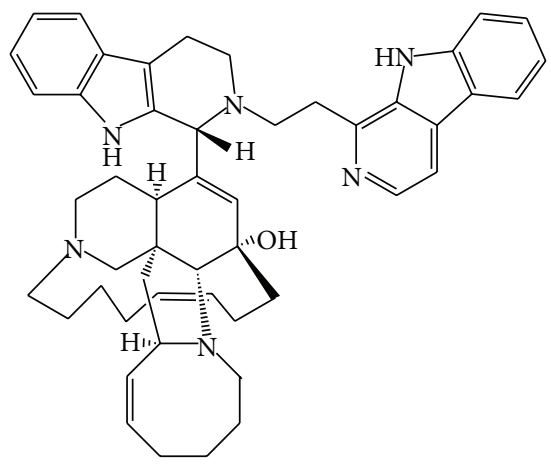

Zamamidine $\mathrm{C}$

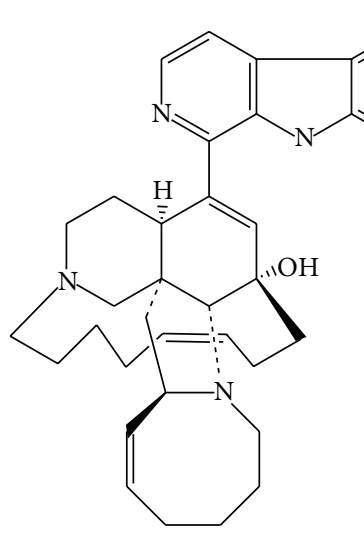<smiles>[R1]c1cc([R2])c2[nH]c3c(C(=C)CCC)nccc3c2c1</smiles>

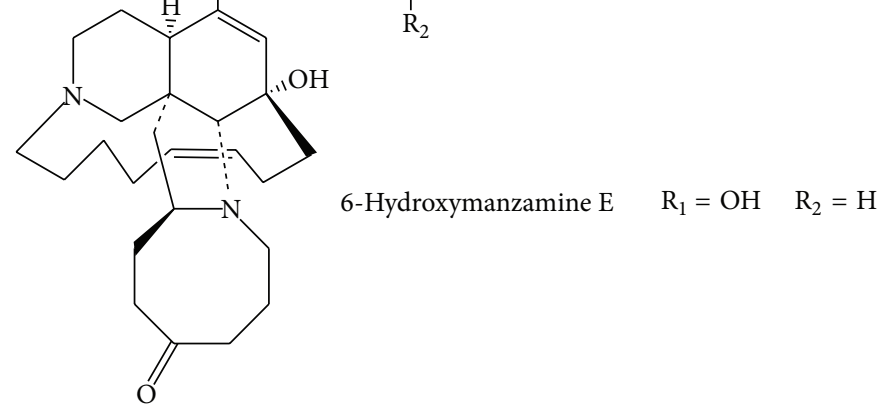

FIGURE 1: Structures of $\beta$-carbolines with manzamine-type frameworks. 
<smiles>[R]c1cc2[nH]c3c(C(=O)c4cc([R3])c(O)c([R4])c4)nccc3c2cc1[R]</smiles>

$$
\begin{array}{lllll}
\text { Eudistomin } \mathrm{Y}_{1} & \mathrm{R}_{1}=\mathrm{H} & \mathrm{R}_{2}=\mathrm{H} & \mathrm{R}_{3}=\mathrm{H} & \mathrm{R}_{4}=\mathrm{H} \\
\text { Eudistomin } \mathrm{Y}_{2} & \mathrm{R}_{1}=\mathrm{Br} & \mathrm{R}_{2}=\mathrm{H} & \mathrm{R}_{3}=\mathrm{H} & \mathrm{R}_{4}=\mathrm{H} \\
\text { Eudistomin } \mathrm{Y}_{3} & \mathrm{R}_{1}=\mathrm{H} & \mathrm{R}_{2}=\mathrm{H} & \mathrm{R}_{3}=\mathrm{Br} & \mathrm{R}_{4}=\mathrm{H} \\
\text { Eudistomin } \mathrm{Y}_{4} & \mathrm{R}_{1}=\mathrm{Br} & \mathrm{R}_{2}=\mathrm{H} & \mathrm{R}_{3}=\mathrm{Br} & \mathrm{R}_{4}=\mathrm{H} \\
\text { Eudistomin } \mathrm{Y}_{5} & \mathrm{R}_{1}=\mathrm{H} & \mathrm{R}_{2}=\mathrm{H} & \mathrm{R}_{3}=\mathrm{Br} & \mathrm{R}_{4}=\mathrm{Br} \\
\text { Eudistomin } \mathrm{Y}_{6} & \mathrm{R}_{1}=\mathrm{Br} & \mathrm{R}_{2}=\mathrm{H} & \mathrm{R}_{3}=\mathrm{Br} & \mathrm{R}_{4}=\mathrm{Br} \\
\text { Eudistomin } \mathrm{Y}_{7} & \mathrm{R}_{1}=\mathrm{H} & \mathrm{R}_{2}=\mathrm{Br} & \mathrm{R}_{3}=\mathrm{Br} & \mathrm{R}_{4}=\mathrm{Br}
\end{array}
$$<smiles>O=C(O)C1=NCCc2c1[nH]c1ccc(O)cc21</smiles>

1-Carboxy-6-hydroxy-3,4-dihydro-b-carboline<smiles>COc1ccc(Br)c2c1[nH]c1c(C)nccc12</smiles>

5-Bromo-8-methoxy-1-methyl-b-carboline

FIGURE 2: Structures of $\beta$-carbolines with eudistomin-derived scaffold and simple $\beta$-carbolines.<smiles>COc1c[nH]c2ccc(O)cc12</smiles>

5-Hydroxy-1H-indole-3-carboxylic acid methyl ester<smiles>COC1(CO)Nc2cc(Br)ccc2C1=O</smiles>

Matemone<smiles>OCCc1c[nH]c2ccccc12</smiles>

Tryptophol<smiles>O=Cc1c[nH]c2ccc(O)cc12</smiles>

5-Hydroxyindole-3-carbaldehyde<smiles>CC(=O)NCC(=O)c1c[nH]c2ccccc12</smiles>

$N$-Acetyl- $\beta$-oxotryptamine<smiles>[R3]c1ccc2c(/C=C3\NC(=[NH2+])NC3=O)c[nH]c2c1</smiles>

Isoplysin

6-Bromo-2' -de- $N$-methylaplysinopsin

6-Bromoaplysinopsin

$$
\begin{array}{llll}
\mathrm{R}_{1}=\mathrm{H} & \mathrm{R}_{2}=\mathrm{CH}_{3} & \mathrm{R}_{3}=\mathrm{CH}_{3} & \mathrm{R}_{4}=\mathrm{H} \\
\mathrm{R}_{1}=\mathrm{Br} & \mathrm{R}_{2}=\mathrm{H} & \mathrm{R}_{3}=\mathrm{H} & \mathrm{R}_{4}=\mathrm{H} \\
\mathrm{R}_{1}=\mathrm{Br} & \mathrm{R}_{2}=\mathrm{CH}_{3} & \mathrm{R}_{3}=\mathrm{H} & \mathrm{R}_{4}=\mathrm{CH}_{3}
\end{array}
$$<smiles>NCCCCNCCCNC(=O)C(=O)c1c[nH]c2ccccc12</smiles>

Didemnidine B<smiles>O=C(CO)c1c[nH]c2ccccc12</smiles>

3-Hydroxyacetylindole

FIGURE 3: Structures of simple indole alkaloids. 
<smiles>O=C1NC[C@@H](c2c[nH]c3cc(Br)ccc23)N[C@@H]1c1c[nH]c2cc(Br)ccc12</smiles>

cis-3,4-Dihydrohamacanthin B<smiles>[NH]CCCc1c[nH]c2c(O)cc(Br)c(-c3c(Br)cc(O)c4[nH]cc(CCNP)c34)c12</smiles>

Dendridine A<smiles>O=C(C(=O)c1c[nH]c2ccc(O)cc12)c1c[nH]c2ccc(O)cc12</smiles>

Hyrtiosin B

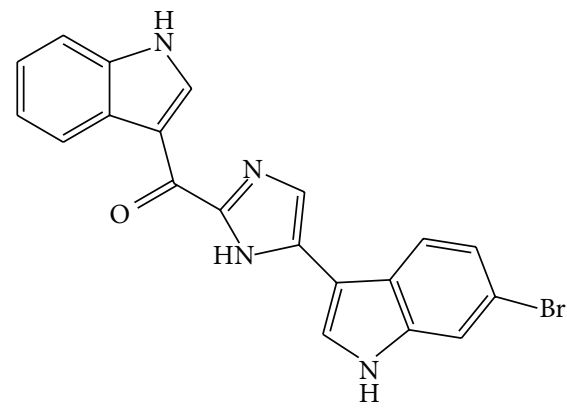

Bromodeoxytopsentin

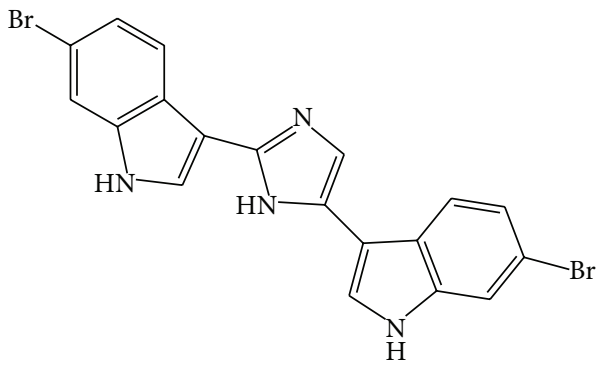

Nortopsentin A

FIgURE 4: Structures of bis-indole alkaloids.

functional group at the C-3 position. A substitution by a hydrophilic group at the C-3 position results in an increase of the isocitrate lyase inhibitory activity [71].

Tryptophol (Figure 3), a simple indole alkaloid from sponge Ircinia spinulosa, was screened for antitrypanosomal activity. The compound was active against $T$. $b$. rhodesiense with an $\mathrm{IC}_{50}$ value of $5.89 \mu \mathrm{g} / \mathrm{mL}$, but it was 8 -fold less active against $T$. cruzi, with $\mathrm{IC}_{50}$ value of $49.37 \mu \mathrm{g} / \mathrm{mL}$, than against T. b. rhodesiense. Toward $L$. donovani, tryptophol displayed an $\mathrm{IC}_{50}$ value of $9.60 \mu \mathrm{g} / \mathrm{mL}$, compared with $0.20 \mu \mathrm{g} / \mathrm{mL}$ of the standard drug, miltefosine. For $P$. falciparum, it was shown that tryptophol presented an $\mathrm{IC}_{50}$ value of $5.08 \mu \mathrm{g} / \mathrm{mL}$, compared with $0.056 \mu \mathrm{g} / \mathrm{mL}$ of chloroquine [72].

A bioactive bromine-containing oxindole alkaloid, matemone (Figure 3), was isolated from the Indian Ocean sponge Iotrochota purpurea. Matemone showed marginal antimicrobial activity against the bacterium Staphylococcus aureus at 50,100 , and $200 \mu \mathrm{g} /$ disk, affording inhibitory zones of 7,9 , and $11 \mathrm{~mm}$, respectively [73].

Dendridine A (Figure 4), a C2-symmetrical 4,4'-bis(7hydroxy) indole alkaloid, was reported in extracts of an Okinawan sponge Dictyodendrilla sp. Dendridine A exhibited inhibitory activities against Gram-positive bacteria Bacillus subtilis and Micrococcus luteus with MIC values of 8.3 and $4.2 \mu \mathrm{g} / \mathrm{mL}$, respectively, and the fungus C. neoformans with MIC of $8.3 \mu \mathrm{g} / \mathrm{mL}$ [74].

In order to discover active compounds with inhibitory activity against methicillin-resistant $S$. aureus pyruvate kinase (MRSA-PK), screening of an extract library of marine invertebrates resulted in the identification of bis-indole alkaloids from the Topsentia pachastrelloides. The most active compounds, cis-3,4-dihydrohamacanthin B and bromodeoxytopsentin (Figure 4), were identified as highly potent MRSA-PK inhibitors with $\mathrm{IC}_{50}$ values of $16-60 \mathrm{nM}$ and with at least 166-fold selectivity over human PK isoforms. These novel anti-PK natural compounds exhibited significant antibacterial activities against MRSA with MIC values of 12.5 and $6.25 \mu \mathrm{g} / \mathrm{mL}$, respectively, and selectivity indices $\left(\mathrm{CC}_{50} / \mathrm{MIC}\right)>4[75]$.

The bis-indole alkaloid nortopsentin A (Figure 4) present in enriched fractions of marine sponges from genus Spongosorites exhibited potent inhibition of Plasmodium falciparum growth. Assays were performed in chloroquinesensitive (3D7) and chloroquine-resistant (Dd2) strains, and $\mathrm{IC}_{50}$ values obtained were $460 \mathrm{nM}$ against the former and $560 \mathrm{nM}$ against the latter [76].

The bisindole alkaloid $(R)-6^{\prime}$-debromohamacanthin B (Figure 4) was isolated from the $\mathrm{MeOH}$ extract of a marine sponge Spongosorites sp. and showed weak antibacterial activity against clinically isolated methicillin-resistant strains, with MIC values of $6.3 \mu \mathrm{g} / \mathrm{mL}$ for $S$. pyogenes $308 \mathrm{~A}$ and $12.5 \mu \mathrm{g} / \mathrm{mL}$ for S. pyogenes 77A, S. aureus SG 511; S. aureus 285; S. aureus 503 [77].

Bis-indole alkaloids isolated from the Jamaican sponge Smenospongia aurea were tested against the D6 clone of P. falciparum for their in vitro antimalarial activity. The compound 6-bromoaplysinopsin (Figure 4) exhibited activity at endpoints of 0.087 and $0.34 \mu \mathrm{g} / \mathrm{mL}$ with a selectivity index of 


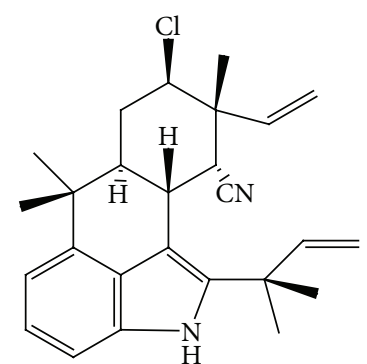

Ambiguine A isonitrile



Ambiguine $\mathrm{H}$ isonitrile

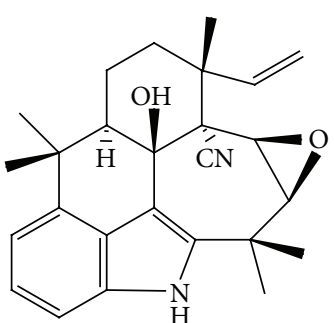

Ambiguine I isonitrile

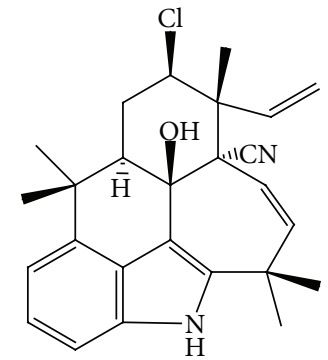

Ambiguine $\mathrm{K}$ isonitrile

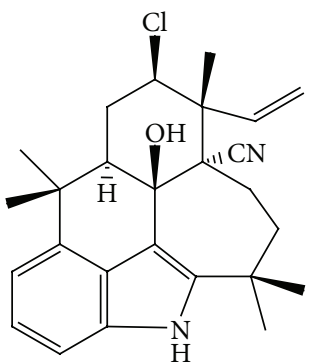

Ambiguine $\mathrm{M}$ isonitrile

FIGURE 5: Structures of ambiguine isonitriles.<smiles>O=C1c2ccccc2-[n+]2ccc3c([nH]c4ccccc43)c21</smiles>

Fascaplysin<smiles>CC(=O)CC1(O)c2ccccc2-[n+]2cc3[nH]c4ccccc4c3cc21</smiles>

Homofascaplysin A

FIGURE 6: Structures of fascaplysin and homofascaplysin A.

55 and 14, respectively. Other compounds such as isoplysin $\mathrm{A}$ and 6-bromo- $2^{\prime}$-de- $N$-methylaplysinopsin (Figure 3) showed moderate activity at $0.97,1.1$, and $0.94 \mu \mathrm{g} / \mathrm{mL}$ with a selectivity index of $>4.9,>4.3$, and $>5.1$, respectively. Moreover, 6-bromo- $2^{\prime}$-de- $N$-methylaplysinopsin inhibited the antimalarial target plasmepsin II enzyme with $\mathrm{IC}_{50}$ $53 \mu \mathrm{M}$ in fluorescence resonance energy transfer (FRET) and $66 \mu \mathrm{M}$ in fluorescence polarization (FP) assays [78].

Bioassay-guided fractionation of the 7:3 MeOH/water extract of a cultured cyanobacterium strain identified as Fischerella sp. yielded nine isonitrile-containing alkaloids. Ambiguine $\mathrm{H}$ isonitrile and ambiguine I (Figure 5) isonitrile exhibited strong activity against the bacteria Staphylococcus albus (MIC values of 0.625 and $0.078 \mu \mathrm{g} / \mathrm{mL}$ ) and B. subtilis (MIC values of 1.25 and $0.312 \mu \mathrm{g} / \mathrm{mL}$ ). Ambiguine I isonitrile was strongly active against the fungi Saccharomyces cerevisiae (MIC value of $0.312 \mu \mathrm{g} / \mathrm{mL}$ ) and C. albicans ATCC 90028 (MIC value of $0.39 \mu \mathrm{g} / \mathrm{mL}$ ) [79].
A new investigation on ambiguines highlighted that ambiguine $\mathrm{A}$ isonitrile showed MIC of $1.0 \mu \mathrm{M}$ against $B$. anthracis, while ambiguine $\mathrm{K}$ and $\mathrm{M}$ isonitriles (Figure 5) were more potent towards $M$. tuberculosis with MIC values of $6.6 \mu \mathrm{M}$ and $7.5 \mu \mathrm{M}$, respectively [80].

From the $\mathrm{CH}_{2} \mathrm{Cl}_{2}$ extract of the sponge Hyrtios cf. erecta, collected in Fiji, $\beta$-carbolines homofascaplysin $\mathrm{A}$ and fascaplysin (Figure 6) were isolated. Evaluation of the biological activity of the compounds toward $P$. falciparum revealed that homofascaplysin and fascaplysin are both potently active in vitro against the parasite. Homofascaplysin A also inhibited the growth of Escherichia coli $(50 \mu \mathrm{g} / 9 \mathrm{~mm})$ and Bacillus megaterium $(50 \mu \mathrm{g} / 11 \mathrm{~mm})$. Fascaplysin inhibited the growth of E. coli $(50 \mu \mathrm{g} / 6 \mathrm{~mm})$ and B. megaterium $(50 \mu \mathrm{g} / 10 \mathrm{~mm})$. Further biological activity for fascaplysin was found against Trypanosoma $b$. rhodesiense, displaying moderate activity with $\mathrm{IC}_{50}$ value of $0.17 \mu \mathrm{g} / \mathrm{mL}$ compared with melarsoprol, which showed $\mathrm{IC}_{50}$ value of $2 \mathrm{ng} / \mathrm{mL}$. 
<smiles>[R]c1ccc(CCNC(=O)c2cc3c([nH]c4ccccc43)c(C(C)=O)n2)cc1</smiles>

Marinacarboline A $\quad \mathrm{R}=\mathrm{OCH}_{3}$ Marinacarboline B $\quad \mathrm{R}=\mathrm{H}$<smiles>C=CC(C)(C)c1ccc(N(C)[C@H](C(=O)N[C@@H](CC)COC)[C@H](C)CC)c2[nH]cc(C)c12</smiles>

Methylpendolmycin-14-O- $\alpha$-glucoside

FIGURE 7: Structures of marinacarbolines and pendolmycin derivative.<smiles>CO[C@H]1[C@@H](N)C[C@@H]2O[C@]1(C)n1c3ccccc3c3c4c(c5c6ccccc6n2c5c31)C(=O)NC4</smiles>

FIGURE 8: Structure of indolocarbazole alkaloid staurosporine.

The evaluation of antiviral activity of fascaplysin revealed an increased cytopathogenic effect at noncytotoxic concentrations of $0.038 \mu \mathrm{g} / \mathrm{mL}$ toward fetal Rhesus monkey kidney cells (FRhK-4-cells) infected with the HAV-variant HAVcytHB1.1. Persistently infected FRhK-4-cells (HAV/7) showed cytopathogenicity at $0.038 \mu \mathrm{g} / \mathrm{mL}$ of fascaplysin, while untreated FRhK-4-cells remained unchanged. Homofascaplysin A and fascaplysin were shown to be potent in vitro inhibitors of chloroquine-susceptible (NF54) and chloroquine-resistant $P$. falciparum strains. Positive control substances were chloroquine and artemisinin. The potency against the K1 strain of homofascaplysin A was stronger than that of chloroquine. Compared with artemisinin (K1 strain) and with both positive control substances (NF54 strain), homofascaplysin was approximately 10 -fold less active [81].

Alkaloids obtained from the fermentation broth of Marinactinospora thermotolerans SCSIO 0652 were tested for their antiplasmodial activities against $P$. falciparum line 3D7, a drug-sensitive strain, and Dd2, a multi-drug-resistant strain. The results of the antiplasmodial assays revealed that marinacarboline A (Figure 7) and methylpendolmycin-14- $O-\alpha$ glucoside (Figure 6) inhibited $P$. falciparum line Dd2 with $\mathrm{IC}_{50}$ values of 1.92 and $5.03 \mu \mathrm{M}$, respectively, and marinacarbolines $\mathrm{C}$ and $\mathrm{D}$ inhibited P. falciparum lines 3D7 and Dd2 with $\mathrm{IC}_{50}$ values between 3.09 and $5.39 \mu \mathrm{M}$ [82].

The cultivation of Streptomyces sp. strains associated with the Mediterranean sponges Aplysina aerophoba, Axinella polypoides, Tedania sp., and Tethya sp., collected in Croatia, has yielded the indolocarbazole alkaloid staurosporine<smiles>O=C1NC(=O)[C@H](Cc2c[nH]c3ccccc23)n2c1nc1ccccc1c2=O</smiles>

FIGURE 9: Structure of pyrazinoquinazoline-derived alkaloid oxoglyantrypine.

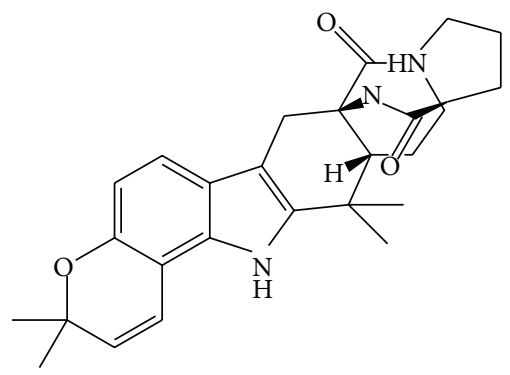

FIGURE 10: Structure of prenylated indole alkaloids (-)-stephacidin A.

(Figure 8). The compound was screened for anti-infective activities and showed significant antiparasitic activity against Leishmania major with $\mathrm{IC}_{50} 5.30 \mu \mathrm{M}$ and T. b. brucei with $\mathrm{IC}_{50}$ $0.022 \mu \mathrm{M}$ [83]. Staurosporine was first isolated in 1977 from Streptomyces staurisporeus and later also from other actinomycetes as well as cyanobacteria. In the meantime several staurosporine analogues were isolated from actinomycetes and also from marine invertebrate, including among others sponges, mollusks, and tunicates. Interestingly, in several cases staurosporine and related derivatives were isolated from Streptomyces sp. The occurrence of such compound may suggest the presence of associated microorganisms responsible for the biosynthesis of staurosporine [84].

A novel indole alkaloid containing pyrazinoquinazolinederivative framework, (14S)-oxoglyantrypine (Figure 9), 
<smiles>[R]c1ccc2c(C(CN(C)C)c3c(O)c(O)c4c5c(nccc35)C=CN4)c[nH]c2c1</smiles>

Nakijinamine A Nakijinamine B

$\mathrm{R}=\mathrm{Br}$
$\mathrm{R}=\mathrm{H}$<smiles>C=C(CC(C)C)Nc1c(O)c(C(CN(C)C)c2c[nH]c3cc(Br)ccc23)c2ccnc3c2c1NC=C3</smiles>

Nakijinamine C

FIGURE 11: Structures of heteroaromatic aaptamine-type indole alkaloids.<smiles>O=C1CC(C(=O)c2c[nH]c3ccc(O)cc23)c2c(O)ccc3[nH]cc(c23)C1=O</smiles>

Hyrtimomine F<smiles>O=C(c1c[nH]c2ccc(O)cc12)[C@H](O)[C@@H](O)C(=O)c1c[nH]c2ccc(O)cc12</smiles>

Hyrtimomine G<smiles></smiles>

Hyrtimomine I<smiles></smiles>

Hyrtimomine A<smiles>O=C(O)CC1=CNc2ccc3oc4c=3c3ccc(O)cc3c=4c3c1c2-c1cc(O)ccc1N3</smiles>

Hyrtimomine B

FIGURE 12: Structures of hyrtimomine-type alkaloids.

isolated from the culture of the mangrove-derived fungus Cladosporium sp. PJX-41 exhibited activity against influenza virus $\mathrm{H} 1 \mathrm{~N} 1$ with $\mathrm{IC}_{50}$ value of $85 \mu \mathrm{M}$ [85].

From marine Aspergillus sp., a prenylated indole alkaloid was isolated and its antibacterial activity was assayed. (-)Stephacidin A (Figure 10) showed MIC value of $21.5 \mu \mathrm{M}$ against $S$. epidermidis [86].

Nakijinamines A, B, and C (Figure 11) have been shown to present antibacterial and antifungal activity. These compounds present a heteroaromatic aaptamine-type framework and a halogenated indole moiety. Nakijinamine A was active against C. albicans $\left(\mathrm{IC}_{50} 0.25 \mu \mathrm{g} / \mathrm{mL}\right), C$. neoformans $\left(\mathrm{IC}_{50}\right.$ $0.5 \mu \mathrm{g} / \mathrm{mL})$, Trichophyton mentagrophytes $\mathrm{IC}_{50}(0.25 \mu \mathrm{g} / \mathrm{mL})$, S. aureus (MIC $16 \mu \mathrm{g} / \mathrm{mL}$ ), B. subtilis (MIC $16 \mu \mathrm{g} / \mathrm{mL}$ ), and Micrococus luteus (MIC $2 \mu \mathrm{g} / \mathrm{mL}$ ). Nakijinamines B and C were only active against $C$. albicans with $\mathrm{IC}_{50}$ value of $8 \mu \mathrm{g} / \mathrm{mL}$ each [87].

Alkaloids with hyrtimomine-type framework (Figure 12) were isolated from Hyrtios spp. Hyrtimomines F, G, and I exhibited inhibitory effects against Aspergillus niger $\left(\mathrm{IC}_{50}\right.$ $8.0 \mu \mathrm{g} / \mathrm{mL}$ each), while hyrtimomine I showed inhibitory effect against $C$. neoformans $\left(\mathrm{IC}_{50} 4.0 \mu \mathrm{g} / \mathrm{mL}\right.$ ). Hyrtimomines $\mathrm{A}$ and $\mathrm{B}$ also showed antifungal activities against $C$. albicans $\left(\mathrm{IC}_{50} 1.0 \mu \mathrm{g} / \mathrm{mL}\right.$ each) and C. neoformans ( $\mathrm{IC}_{50} 2.0$ and $4.0 \mu \mathrm{g} / \mathrm{mL}$, resp.). Hyrtimomine A exhibited an inhibitory activity against $A$. niger $\left(\mathrm{IC}_{50} 4.0 \mu \mathrm{g} / \mathrm{mL}\right)$ [88].

Meridianins A-G (Figure 13) comprise indole alkaloids substituted at the C-3 position by a 2 -aminopyridine ring and had been previously isolated from the tunicate Aplidium meridianum. Investigations on the antimalarial and antileishmanial activity of meridianin $\mathrm{C}$ and $\mathrm{G}$ were carried out and showed that these two compounds inhibited P. falciparum D6 and W2 clones with $\mathrm{IC}_{50}$ values in the range of 4.4 to 14.4 $\mu \mathrm{M}$. Meridianin $\mathrm{C}$ was also active against $L$. donovani promastigotes showing an $\mathrm{IC}_{50}$ value of $64 \mu \mathrm{M}$ [89].

Simple indole-derived alkaloids were isolated from the marine bacterium Bacillus pumilus. Compounds 3-hydroxyacetylindole and $N$-acetyl- $\beta$-oxotryptamine 
<smiles>Nc1nccc(-c2c[nH]c3ccc(Br)cc23)n1</smiles>

Meridianin C<smiles>Nc1nccc(-c2c[nH]c3ccccc23)n1</smiles>

Meridianin G
FIgURE 13: Structures of meridianins C and G.<smiles>[R6]Oc1ccc2[nH]c3cnc(-c4c[nH]c5cc(O)ccc45)c([R])c3c2c1</smiles>

$$
\begin{array}{lll}
\text { Hyrtioerectine D } & \mathrm{R}_{1}=\mathrm{COOH} & \mathrm{R}_{2}=\mathrm{H} \\
\text { Hyrtioerectine E } & \mathrm{R}_{1}=\mathrm{COOH} & \mathrm{R}_{2}=\mathrm{CH}_{3} \\
\text { Hyrtioerectine F } & \mathrm{R}_{1}=\mathrm{CONH}_{2} & \mathrm{R}_{2}=\mathrm{H}
\end{array}
$$

FIgURE 14: Structures of hyrtioerectines D-F.

(Figure 3) promoted inhibition on the growth of amastigotes from $T$. cruzi with $\mathrm{IC}_{50}$ values of 20.6 and $19.4 \mu \mathrm{M}$, respectively [90].

Hyrtioerectines D-F (Figure 14) were isolated from Hyrtios species and had their antimicrobial activities screened. These $\beta$-carboline-derived compounds showed inhibition zones of 17,9 , and $14 \mathrm{~mm}$ against $C$. albicans compared to $35 \mathrm{~mm}$ illustrated by clotrimazole at the same concentration. In addition, they caused inhibition zones of 20,10 , and $16 \mathrm{~mm}$ against $S$. aureus, respectively, compared to $30 \mathrm{~mm}$ illustrated by ampicillin, as well as inhibition zones of $7-9 \mathrm{~mm}$ against Pseudomonas aeruginosa compared to $30 \mathrm{~mm}$ illustrated by imipenem [91].

As noted in the study above, the main source of marine indole alkaloids are sponges, whilst pharmacological assays focus on activity toward parasites from the genus Plasmodium and Trypanosoma. Although few indole alkaloids from marine sources have been tested for anti-infective activity, there are some promising compounds which demonstrate high level of activity against several infectious diseases agents including bacteria, fungi, and protozoa. These active alkaloids show simple as well as complex frameworks and unlike terrestrial organisms, they frequently contain halogenated moieties. Therefore this review highlighted some marine indole alkaloids which may be considered as potential starting points for the development of novel agents for the treatment of infectious diseases.

\section{Conflict of Interests}

The authors declare that there is no conflict of interests regarding the publication of this paper.

\section{Acknowledgments}

Financial support was provided by $\mathrm{CNPq}$ (Conselho Nacional de Desenvolvimento Científico e Tecnológico), PRONEXFAPESQ-PB (Programa de Apoio a Núcleos de ExcelênciaFundação de Apoio a Pesquisa do Estado da Paraíba) and INCT AmbTropic (http://www.inctambtropic.org/).

\section{References}

[1] L. V. Costa-lotufo, D. V. Wilke, P. C. Jimenez, and R. D. A. Epifanio, "Marine organisms as a source of new pharmaceuticals: history and perspectives," Química Nova, vol. 32, no. 3, pp. 703716, 2009.

[2] J. V. Rao, P. K. Usman, and J. B. Kumar, "Larvicidal and insecticidal properties of some marine sponges collected in Palk Bay and Gulf of Mannar waters," African Journal of Biotechnology, vol. 7, no. 2, pp. 109-113, 2008.

[3] M. Donia and M. T. Hamann, "Marine natural products and their potential applications as anti-infective agents," The Lancet Infectious Diseases, vol. 3, no. 6, pp. 338-348, 2003.

[4] É. T. de Souza, D. P. de Lira, A. C. de Queiroz et al., "The antinociceptive and anti-inflammatory activities of caulerpin, a bisindole alkaloid isolated from seaweeds of the genus Caulerpa," Marine Drugs, vol. 7, no. 4, pp. 689-704, 2009.

[5] K. C. Güven, A. Percot, and E. Sezik, "Alkaloids in marine algae," Marine Drugs, vol. 8, no. 2, pp. 269-284, 2010.

[6] S. Sagar, M. Kaur, and K. P. Minneman, "Antiviral lead compounds from marine sponges," Marine Drugs, vol. 8, no. 10, pp. 2619-2638, 2010.

[7] A. Longeon, B. R. Copp, E. Quévrain et al., "Bioactive indole derivatives from the South Pacific marine sponges Rhopaloeides odorabile and Hyrtios sp," Marine Drugs, vol. 9, no. 5, pp. 879-888, 2011.

[8] W. Gul and M. T. Hamann, "Indole alkaloid marine natural products: an established source of cancer drug leads with considerable promise for the control of parasitic, neurological and other diseases," Life Sciences, vol. 78, no. 5, pp. 442-453, 2005.

[9] A. M. P. Almeida, R. G. S. Berlinck, and E. Hajdu, "Alcalóides alquilpiridínicos de esponjas marinhas," Química Nova, vol. 20, pp. 170-185, 1997.

[10] M. Kitajima, K. Misawa, N. Kogure et al., "A new indole alkaloid, 7-hydroxyspeciociliatine, from the fruits of Malaysian Mitragyna speciosa and its opioid agonistic activity," Journal of Natural Medicines, vol. 60, no. 1, pp. 28-35, 2006.

[11] J. C. A. Tanaka, C. C. da Silva, A. J. B. de Oliveira, C. V. Nakamura, and B. P. Dias Filho, "Antibacterial activity of indole alkaloids from Aspidosperma ramiflorum," Brazilian Journal Of Medical and Biological Research, vol. 39, pp. 387-391, 2006.

[12] R. B. Williams, J. Hu, K. M. Olson et al., "Antibiotic indole sesquiterpene alkaloid from Greenwayodendron suaveolens with a new natural product framework," Journal of Natural Products, vol. 73, no. 5, pp. 1008-1011, 2010.

[13] F. Soriano-Agatón, D. Lagoutte, E. Poupon et al., "Extraction, hemisynthesis, and synthesis of canthin-6-one analogues. Evaluation of their antifungal activities," Journal of Natural Products, vol. 68, no. 11, pp. 1581-1587, 2005.

[14] J. Zhang, J. Gao, T. Xua et al., "Antifungal activity of alkaloids from the seeds of Chimonanthus praecox," Chemistry and Biodiversity, vol. 6, no. 6, pp. 838-845, 2009. 
[15] Y. Chen, P. Kuo, H. Chan et al., " $\beta$-carboline alkaloids from Stellaria dichotoma var. lanceolata and their anti-inflammatory activity," Journal of Natural Products, vol. 73, no. 12, pp. 19931998, 2010.

[16] E. V. Costa, M. L. B. Pinheiro, C. M. Xavier et al., "A pyrimidine$\beta$-carboline and other alkaloids from Annona foetida with antileishmanial activity," Journal of Natural Products, vol. 69, no. 2, pp. 292-294, 2006.

[17] J. C. Delorenzi, M. Attias, C. R. Gattass et al., "Antileishmanial activity of an indole alkaloid from Peschiera australis," Antimicrobial Agents and Chemotherapy, vol. 45, no. 5, pp. 1349-1354, 2001.

[18] G. Philippe, P. de Mol, M. Zèches-Hanrot et al., "Indolomonoterpenic alkaloids from Strychnos icaja roots," Phytochemistry, vol. 62, no. 4, pp. 623-629, 2003.

[19] R. Verpoorte, M. Frédérich, C. Delaude et al., "Moandaensine, a dimeric indole alkaloid from Strychnos moandaensis (Loganiaceae)," Phytochemistry Letters, vol. 3, no. 2, pp. 100-103, 2010.

[20] H. Zhou, H. He, X. Luo et al., "Three new indole alkaloids from the leaves of Alstonia scholaris," Helvetica Chimica Acta, vol. 88, no. 9, pp. 2508-2512, 2005.

[21] T. Feng, Y. Li, X. Cai et al., "Monoterpenoid indole alkaloids from Alstonia yunnanensis," Journal of Natural Products, vol. 72, no. 10, pp. 1836-1841, 2009.

[22] H. Shittu, A. Gray, B. Furman, and L. Young, "Glucose uptake stimulatory effect of akuammicine from Picralima nitida (Apocynaceae)," Phytochemistry Letters, vol. 3, no. 1, pp. 53-55, 2010.

[23] M. Miyazawa, J. Fujioka, and Y. Ishikawa, "Insecticidal compounds from Evodia rutaecarpa against Drosophila melanogaster," Journal of the Science of Food and Agriculture, vol. 82, no. 13, pp. 1574-1578, 2002.

[24] I. Ngantchou, B. Nyasse, C. Denier, C. Blonski, V. Hannaert, and B. Schneider, "Antitrypanosomal alkaloids from Polyalthia suaveolens (Annonaceae): their effects on three selected glycolytic enzymes of Trypanosoma brucei," Bioorganic and Medicinal Chemistry Letters, vol. 20, no. 12, pp. 3495-3498, 2010.

[25] Y. Hirasawa, M. Hara, A. E. Nugroho et al., "Bisnicalaterines $\mathrm{B}$ and $\mathrm{C}$, atropisomeric bisindole alkaloids from hunteria zeylanica, showing vasorelaxant activity," Journal of Organic Chemistry, vol. 75, no. 12, pp. 4218-4223, 2010.

[26] K. Koyama, Y. Hirasawa, K. Zaima, T. C. Hoe, K. Chan, and H. Morita, "Alstilobanines A-E, new indole alkaloids from Alstonia angustiloba," Bioorganic and Medicinal Chemistry, vol. 16, no. 13, pp. 6483-6488, 2008.

[27] A. P. G. MacAbeo, W. S. Vidar, X. Chen et al., "Mycobacterium tuberculosis and cholinesterase inhibitors from Voacanga globosa," European Journal of Medicinal Chemistry, vol. 46, no. 7, pp. 3118-3123, 2011.

[28] H. C. Brastianos, E. Vottero, B. O. Patrick et al., "Exiguamine A, an indoleamine-2,3-dioxygenase (IDO) inhibitor isolated from the marine sponge Neopetrosia exigua," Journal of the American Chemical Society, vol. 128, no. 50, pp. 16046-16047, 2006.

[29] S. Martínez-Luis, R. Rodríguez, L. Acevedo, M. C. González, A. Lira-Rocha, and R. Mata, "Malbrancheamide, a new calmodulin inhibitor from the fungus Malbranchea aurantiaca," Tetrahedron, vol. 62, no. 8, pp. 1817-1822, 2006.

[30] M. Kitajima, M. Iwai, R. Kikura-Hanajiri et al., "Discovery of indole alkaloids with cannabinoid CB1 receptor antagonistic activity," Bioorganic and Medicinal Chemistry Letters, vol. 21, no. 7, pp. 1962-1964, 2011.
[31] P. Cos, A. J. Vlietinck, D. V. Berghe, and L. Maes, "Anti-infective potential of natural products: How to develop a stronger in vitro 'proof-of-concept"', Journal of Ethnopharmacology, vol. 106, no. 3, pp. 290-302, 2006.

[32] E. Galeano, A. Martínez, O. P. Thomas, S. Robledo, and D. Munoz, "Antiparasitic bromotyrosine derivatives from the caribbean marine sponge aiolochroia crassa," Química Nova, vol. 35, no. 6, pp. 1189-1193, 2012.

[33] F. M. M. Amaral, M. N. S. Ribeiro, J. M. Barbosa-Filho, A. S. Reis, F. R. F. Nascimento, and R. O. Macedo, "Plants and chemical constituents with giardicidal activity," Revista Brasileira de Farmacognosia, vol. 16, pp. 696-720, 2006.

[34] N. C. Andrade, E. V. L. Cunha, M. S. da Silva, M. F. Angra, and J. M. Barbosa-Filho, "Terpenoids of the Annonaceae: distribution and compilation of ${ }^{13} \mathrm{C}$ NMR data," in Recent Research Developments in Phytochemistry, A. Gayathri, Ed., pp. 1-85, Research Signpost, Kerala, India, 2003.

[35] J. Barbosa-Filho, E. Vasconcelos Leitão da-Cunha, and A. I. Gray, "Alkaloids of the menispermaceae," in Alkaloids: Chemistry and Biology, pp. 1-190, Academic Press, 2000.

[36] J. M. Barbosa Filho, I. M. F. Sette, E. V. L. da Cunha, D. N. Guedes, and M. S. Silva, "Protoberberine alkaloids," in The Alkaloids, G. A. Cordell, Ed., p. 75, Elsevier, Amsterdam, The Netherlands, 2005.

[37] J. M. Barbosa-Filho, T. H. C. Vasconcelos, A. A. Alencar, L. M. Batista, R. A. G. Oliveira, and D. N. Guedes, "Plants and their active constituents from South, Central, and North America with hypoglycemic activity," Revista Brasileira de Farmacognosia, vol. 15, pp. 392-413, 2005.

[38] J. M. Barbosa-Filho, M. R. Piuvezam, M. D. Moura et al., "Antiinflammatory activity of alkaloids: a twenty-century review," Revista Brasileira de Farmacognosia, vol. 16, pp. 109-139, 2006.

[39] J. M. Barbosa Filho, K. C. Paula Medeiros, M. F. F. M. Diniz et al., "Natural products inhibitors of the enzyme acetylcholinesterase," Revista Brasileira de Farmacognosia, vol. 16, pp. 258-285, 2006.

[40] J. M. Barbosa-Filho, V. K. M. Martins, L. A. Rabelo et al., "Natural products inhibitors of the angiotensin converting enzyme (ACE): a review between 1980-2000," Revista Brasileira de Farmacognosia, vol. 16, pp. 421-446, 2006.

[41] J. M. Barbosa-Filho, F. A. do Nascimento Júnior, A. C. de Andrade Tomaz et al., "Natural products with antileprotic activity," Brazilian Journal of Pharmacognosy, vol. 17, no. 1, pp. 141-148, 2007.

[42] J. M. Barbosa-Filho, A. A. Alencar, X. P. Nunes et al., "Sources of alpha-, beta-, gamma-, delta- and epsilon-carotenes: a twentieth century review," Brazilian Journal of Pharmacognosy, vol. 18, no. 1, pp. 135-154, 2008.

[43] L. M. Conserva, C. A. B. Pereira, and J. M. Barbosa-Filho, "Alkaloids of the Hernandiaceae: occurrence and a compilation of their biological activities," in Alkaloids: Chemistry and Biology, G. A. Cordell, Ed., pp. 175-243, Academic Press, 2005.

[44] H. de Sousa Falcão, J. A. Leite, J. M. Barbosa-Filho et al., "Gastric and duodenal antiulcer activity of alkaloids: a review," Molecules, vol. 13, no. 12, pp. 3198-3223, 2008.

[45] M. C. R. Gonçalves, L. S. A. Moura, L. A. Rabelo, J. M. Barbosa-Filho, H. M. M. Cruz, and J. Cruz, "Produtos naturais inibidores da enzima HMG CoA redutase," Revista Brasileira de Farmacognosia, vol. 81, pp. 63-71, 2000.

[46] N. S. Lira, R. C. Montes, J. F. Tavares et al., "Brominated compounds from marine sponges of the genus aplysina and a 
compilation of their ${ }^{13} \mathrm{C}$ NMR spectral data," Marine Drugs, vol. 9, no. 11, pp. 2316-2368, 2011.

[47] L. C. S. L. Morais, J. M. Barbosa-Filho, and R. N. Almeida, "Plants and bioactive compounds for the treatment of Parkinson's disease," Arquivos Brasileiros de Fitomedicina Científica, vol. 1, pp. 127-132, 2003.

[48] K. S. de Lira Mota, G. E. N. Dias, M. E. F. Pinto et al., "Flavonoids with gastroprotective activity," Molecules, vol. 14, no. 3, pp. 9791012, 2009.

[49] S. L. Oliveira, M. S. da Silva, J. F. Tavares et al., "Tropane alkaloids from erythroxylum genus: distribution and compilation of ${ }^{13}$ C-NMR spectral data," Chemistry and Biodiversity, vol. 7, no. 2, pp. 302-326, 2010.

[50] S. Palmeira Júnior, L. Conserva, and J. Barbosa-Filho, "Clerodane diterpenes from Croton species: distribution and the compilation of their ${ }^{13} \mathrm{C}$ NMR spectral data," Natural Product Communications, vol. 1, pp. 319-344.

[51] L. G. Rocha, J. R. G. S. Almeida, R. O. Macêdo, and J. M. Barbosa-Filho, "A review of natural products with antileishmanial activity," Phytomedicine, vol. 12, no. 6-7, pp. 514-535, 2005.

[52] A. L. Souto, J. F. Tavares, M. S. da Silva, M. F. F. M. de Diniz, P. F. de Athayde-Filho, and J. M. Barbosa Filho, "Anti-inflammatory activity of alkaloids: an update from 2000 to 2010," Molecules, vol. 16, no. 10, pp. 8515-8534, 2011.

[53] J. G. Sena Filho, J. Duringer, G. L. A. Maia et al., "Ecdysteroids from Vitex species: distribution and compilation of their ${ }^{13} \mathrm{C}$ NMR spectral data," Chemistry and Biodiversity, vol. 5, no. 5, pp. 707-713, 2008.

[54] J. X. de Araújo-Júnior, C. Antheaume, R. C. P. Trindade, M. Schmitt, J. Bourguignon, and A. E. G. Sant'Ana, "Isolation and characterisation of the monoterpenoid indole alkaloids of Aspidosperma pyrifolium," Phytochemistry Reviews, vol. 6, no. 1, pp. 183-188, 2007.

[55] J. X. de Araújo-Júnior, E. V. L. da-Cunha, M. C. D. O. Chaves, and A. I. Gray, "Piperdardine, a piperidine alkaloid from Piper tuberculatum," Phytochemistry, vol. 44, no. 3, pp. 559-561, 1997.

[56] J. X. de Araújo-Júnior, M. S. G. de Oliveira, P. G. V. Aquino, M. S. Alexandre-Moreira, and A. E. G. Sant'Ana, "A phytochemical and ethnopharmacological review of the genus Erythrina," in Phytochemicals: A Global Perspective of Their Role in Nutrition and Health, V. Rao, Ed., InTech, 2012.

[57] H. S. Falcão, I. O. Lima, V. L. dos Santos et al., "Review of the plants with anti-inflammatory activity studied in Brazil," in Revista Brasileira de Farmacognosia, vol. 15, pp. 381-391, 2005.

[58] G. L. de Azevedo Maia, V. D. S. Santos Falcão-Silva, P. G. V. Aquino et al., "Flavonoids from Praxelis clematidea R.M. King and Robinson modulate bacterial drug resistance," Molecules, vol. 16, no. 6, pp. 4828-4835, 2011.

[59] I. R. Mariath, H. D. S. Falcão, J. M. Barbosa-Filho et al., "Plants of the American continent with antimalarial activity," Brazilian Journal of Pharmacognosy, vol. 19, pp. 158-192, 2009.

[60] S. L. de Oliveira, J. F. Tavares, M. V. S. C. Branco et al., "Tropane alkaloids from erythroxylum caatingae plowman," Chemistry and Biodiversity, vol. 8, no. 1, pp. 155-165, 2011.

[61] G. L. Pessini, P. G. V. Aquino, V. B. Bernardo et al., "Evaluation of antimicrobial activity of three Aspidosperma species," Pharmacologyonline, vol. 1, no. 1, pp. 112-119, 2012.

[62] J. R. Filho, H. de Sousa Falcão, L. M. Batista, J. M. B. Filho, and M. R. Piuvezam, "Effects of plant extracts on HIV-1 protease," Current HIV Research, vol. 8, no. 7, pp. 531-544, 2010.
[63] L. J. Q. Júnior, J. R. G. S. Almeida, J. T. Lima et al., "Plants with anticonvulsant properties: a review," Revista Brasileira de Farmacognosia, vol. 18, pp. 798-819, 2008.

[64] J. Peng, J. Hu, A. B. Kazi et al., "Manadomanzamines A and B: a Novel Alkaloid Ring system with potent activity against Mycobacteria and HIV-1," Journal of the American Chemical Society, vol. 125, no. 44, pp. 13382-13386, 2003.

[65] K. K. H. Ang, M. J. Holmes, T. Higa, M. T. Hamann, and U. A. K. Kara, "In vivo antimalarial activity of the betacarboline alkaloid manzamine A," Antimicrobial Agents and Chemotherapy, vol. 44, no. 6, pp. 1645-1649, 2000.

[66] K. V. Rao, M. S. Donia, J. Peng et al., "Manzamine B and E and ircinal A related alkaloids from an Indonesian Acanthostrongylophora sponge and their activity against infectious, tropical parasitic, and Alzheimer's diseases," Journal of Natural Products, vol. 69, no. 7, pp. 1034-1040, 2006.

[67] M. Yamada, Y. Takahashi, T. Kubota et al., "Zamamidine C, 3,4-dihydro-6-hydroxy-10,11-epoxymanzamine A, and 3,4dihydromanzamine J $\mathrm{N}$-oxide, new manzamine alkaloids from sponge Amphimedon sp," Tetrahedron, vol. 65, no. 11, pp. 23132317, 2009.

[68] W. Wang, S. Nam, B. Lee, and H. Kang, " $\beta$-carboline alkaloids from a Korean tunicate Eudistoma sp," Journal of Natural Products, vol. 71, no. 2, pp. 163-166, 2008.

[69] R. Finlayson, A. N. Pearce, M. J. Page et al., "Didemnidines $\mathrm{A}$ and $\mathrm{B}$, indole spermidine alkaloids from the New Zealand ascidian didemnum sp," Journal of Natural Products, vol. 74, no. 4, pp. 888-892, 2011.

[70] M. Till and M. R. Prinsep, "5-bromo-8-methoxy-1-methyl- $\beta$ carboline, an Alkaloid from the New Zealand Marine Bryozoan Pterocella Wesiculosa," Journal of Natural Products, vol. 72, no. 4, pp. 796-798, 2009.

[71] H. Lee, K. Yoon, Y. Han et al., "5-hydroxyindole-type alkaloids, as Candida albicans isocitrate lyase inhibitors, from the tropical sponge Hyrtios sp," Bioorganic and Medicinal Chemistry Letters, vol. 19, no. 4, pp. 1051-1053, 2009.

[72] I. Orhan, B. Şener, M. Kaiser, R. Brun, and D. Tasdemir, "Inhibitory activity of marine sponge-derived natural products against parasitic protozoa," Marine Drugs, vol. 8, no. 1, pp. 47$58,2010$.

[73] I. Carletti, B. Banaigs, and P. Amade, "Matemone, a new bioactive bromine-containing oxindole alkaloid from the indian ocean sponge Iotrochota purpurea," Journal of Natural Products, vol. 63, no. 7, pp. 981-983, 2000.

[74] M. Tsuda, Y. Takahashi, J. Fromont, Y. Mikami, and J. Kobayashi, "Dendridine A, a Bis-indole alkaloid from a marine sponge Dictyodendrilla species," Journal of Natural Products, vol. 68, no. 8, pp. 1277-1278, 2005.

[75] R. Zoraghi, L. Worrall, R. H. See et al., "Methicillin-resistant Staphylococcus aureus (MRSA) pyruvate kinase as a target for bis-indole alkaloids with antibacterial activities," The Journal of Biological Chemistry, vol. 286, no. 52, pp. 44716-44725, 2011.

[76] S. Alvarado, B. F. Roberts, A. E. Wright, and D. Chakrabarti, "The bis(Indolyl)imidazole alkaloid nortopsentin a exhibits antiplasmodial activity" Antimicrobial Agents and Chemotherapy, vol. 57, no. 5, pp. 2362-2364, 2013.

[77] Q. Bao, Q. Sun, X. Yao et al., "Bisindole alkaloids of the topsentin and hamacanthin classes from a marine sponge Spongosorites sp," Journal of Natural Products, vol. 70, no. 1, pp. 2-8, 2007.

[78] J. Hu, J. A. Schetz, M. Kelly et al., "New antiinfective and human 5-HT2 receptor binding natural and semisynthetic compounds 
from the Jamaican sponge Smenospongia aurea, Journal of Natural Products, vol. 65, no. 4, pp. 476-480, 2002.

[79] A. Raveh and S. Carmeli, "Antimicrobial ambiguines from the cyanobacterium Fischerella sp. collected in Israel," Journal of Natural Products, vol. 70, no. 2, pp. 196-201, 2007.

[80] S. Mo, A. Krunic, G. Chlipala, and J. Orjala, "Antimicrobial ambiguine isonitriles from the cyanobacterium Fischerella ambigua," Journal of Natural Products, vol. 72, no. 5, pp. 894899, 2009.

[81] G. Kirsch, G. M. Köng, A. D. Wright, and R. Kaminsky, "A new bioactive sesterterpene and antiplasmodial alkaloids from the marine sponge Hyrtios cf. erecta," Journal of Natural Products, vol. 63, no. 6, pp. 825-829, 2000.

[82] H. Huang, Y. Yao, Z. He et al., "Antimalarial $\beta$-carboline and indolactam alkaloids from Marinactinospora thermotolerans, a deep sea isolate," Journal of Natural Products, vol. 74, no. 10, pp. 2122-2127, 2011.

[83] S. M. Pimentel-Elardo, S. Kozytska, T. S. Bugni, C. M. Ireland, H. Moll, and U. Hentschel, "Anti-parasitic compounds from Streptomyces sp. strains isolated from Mediterranean sponges," Marine Drugs, vol. 8, no. 2, pp. 373-380, 2010.

[84] M. A. Andréo, P. C. Jimenez, J. B. C. N. Siebra et al., "Systematic UPLC-ESI-MS/MS study on the occurrence of staurosporine and derivatives in associated marine microorganisms from Eudistoma vannamei," Journal of the Brazilian Chemical Society, vol. 23, no. 2, pp. 335-343, 2012.

[85] J. Peng, T. Lin, W. Wang et al., "Antiviral alkaloids produced by the mangrove-derived fungus Cladosporium sp. PJX-41," Journal of Natural Products, vol. 76, no. 6, pp. 1133-1140, 2013.

[86] M. Chen, C. Shao, X. Fu et al., "Bioactive indole alkaloids and phenyl ether derivatives from a marine-derived Aspergillus sp. fungus," Journal of Natural Products, vol. 76, no. 4, pp. 547-553, 2013.

[87] Y. Takahashi, N. Tanaka, T. Kubota et al., "Heteroaromatic alkaloids, nakijinamines, from a sponge Suberites sp," Tetrahedron, vol. 68, no. 41, pp. 8545-8550, 2012.

[88] N. Tanaka, R. Momose, A. Tsubasa-Nakaguchi, T. Gonoi, J. Fromont, and J. Kobayashi, "Hyrtimomines, indole alkaloids from Okinawan sponges Hyrtios spp," Tetrahedron, vol. 70, p. 832, 2014.

[89] S. B. Bharate, R. R. Yadav, S. I. Khan et al., "Meridianin G and its analogs as antimalarial agents," MedChem Comm, vol. 4, no. 6, pp. 1042-1048, 2013.

[90] S. Martínez-Luis, J. F. Gómez, C. Spadafora, H. M. Guzmán, and M. Gutiérrez, "Antitrypanosomal alkaloids from the marine bacterium Bacillus pumilus," Molecules, vol. 17, no. 9, pp. 11146$11155,2012$.

[91] D. T. A. Youssef, L. A. Shaala, and H. Z. Asfour, "Bioactive compounds from the Red Sea marine sponge Hyrtios species," Marine Drugs, vol. 11, no. 4, pp. 1061-1070, 2013. 

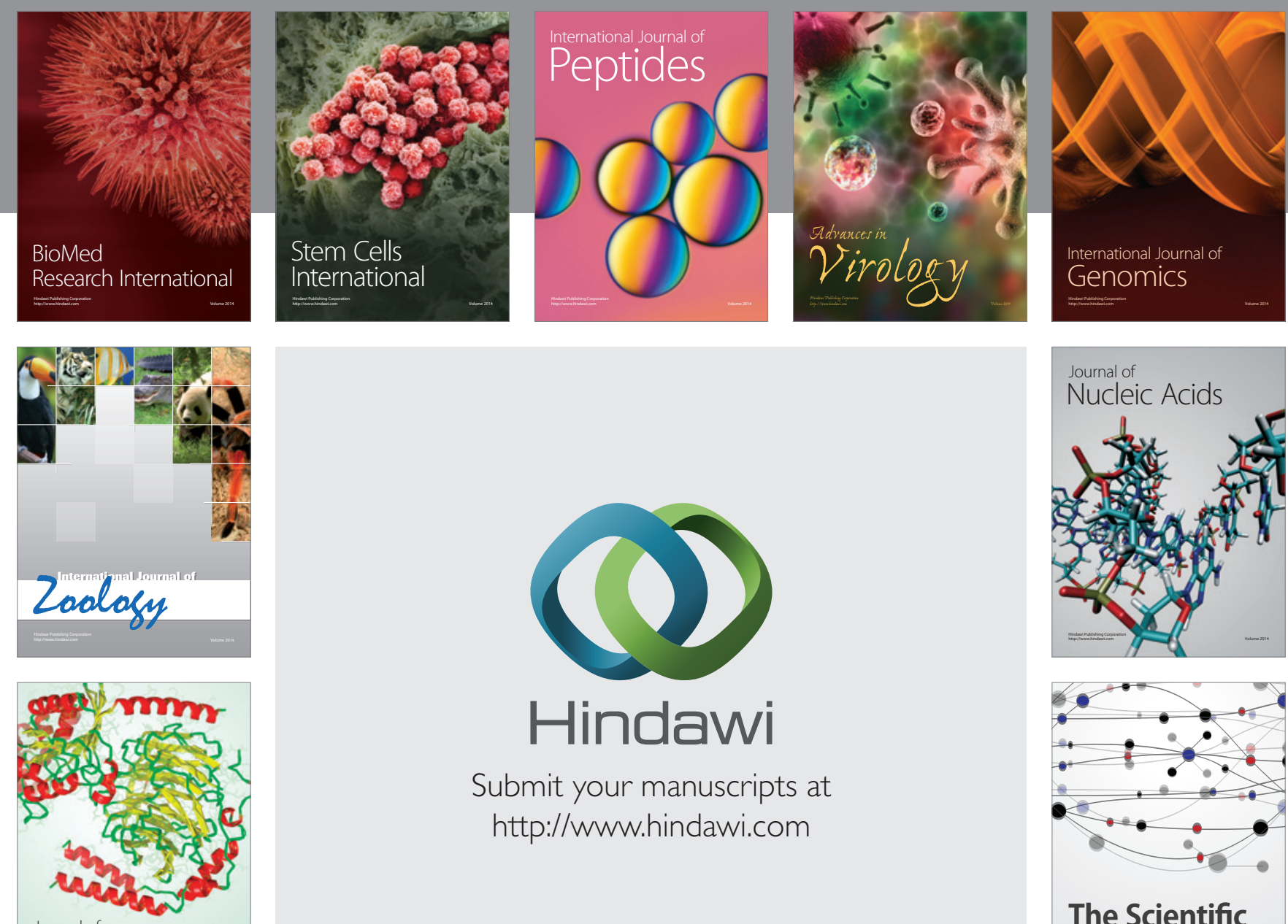

Submit your manuscripts at

http://www.hindawi.com

Journal of
Signal Transduction
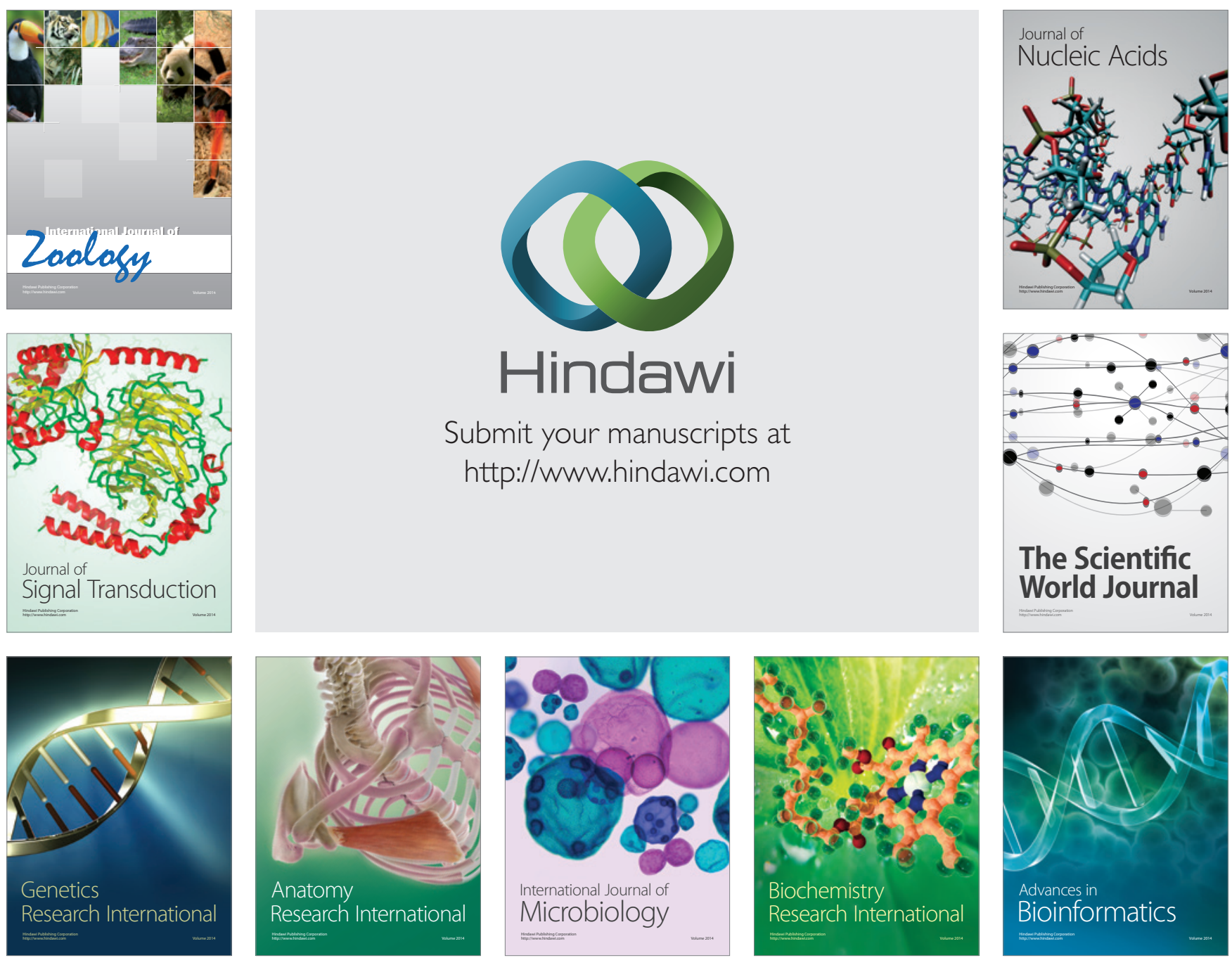

The Scientific World Journal
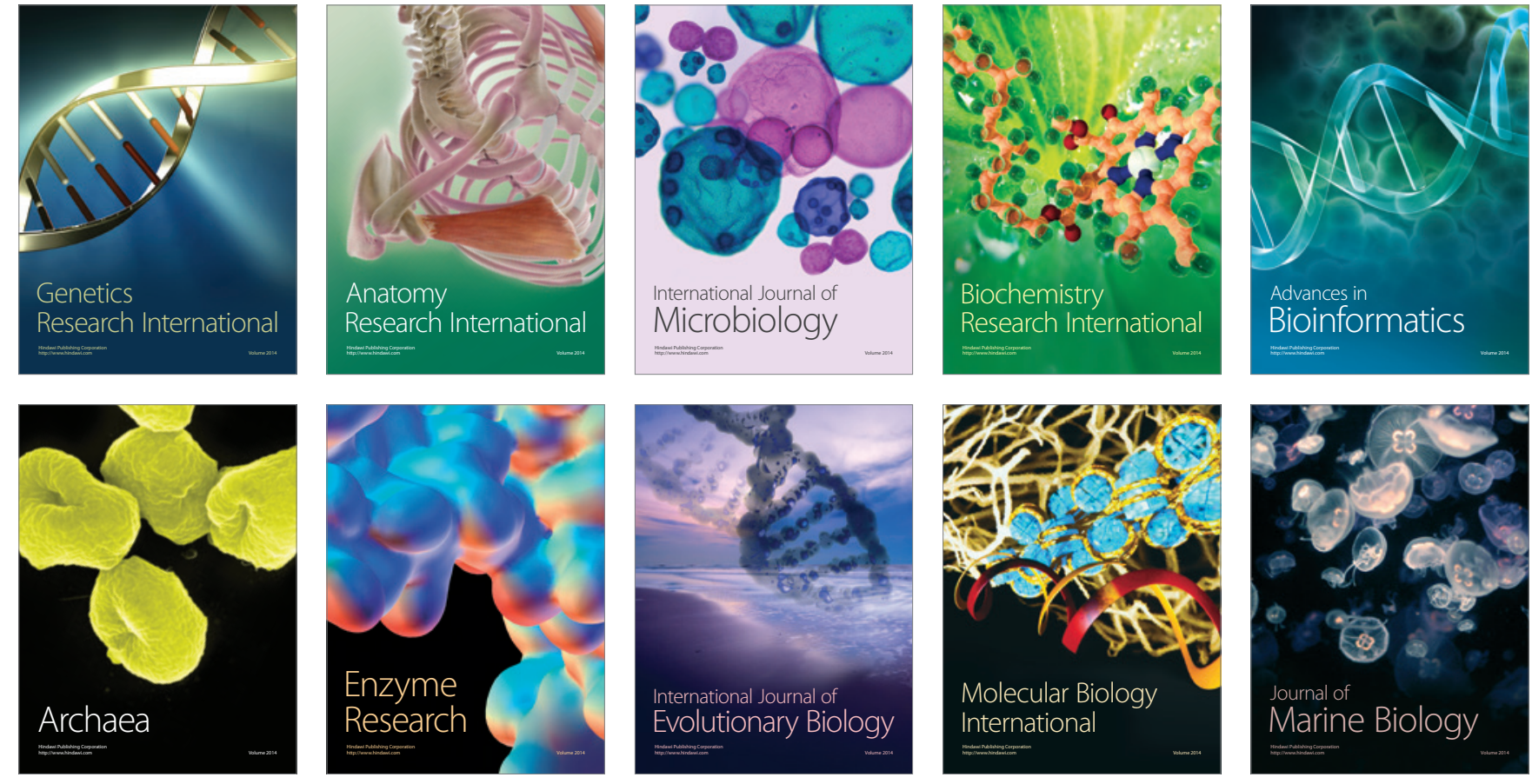